\title{
Implementasi Graphical User Interface (GUI) MATLAB Untuk Analisis Spektrum Biosensor Berbasis Surface Plasmon Resonance (SPR)
}

\author{
Devi Taufiq Nurrohman ${ }^{1}$, Riyadi Purwanto ${ }^{2}$ \\ ${ }^{1}$ Jurusan Teknik Elektronika, Politeknik Negeri Cilacap, Cilacap 53212, Indonesia \\ 2 Jurusan Teknik Informatika, Politeknik Negeri Cilacap, Cilacap 53212, Indonesia \\ E-mail: devi.taufiq.n@mail.ugm.ac.id ${ }^{1 *}$; mailto:adidok_bayu@yahoo.com ${ }^{2}$
}

Received: 0802 2018. Revised: 0905 2018. Accepted: 12072018

\begin{abstract}
Abstrak
Penelitian ini bertujuan untuk membuat aplikasi sederhana menggunakan GUI MATLAB untuk menganalisis spektrum biosensor berbasis Surface Plasmon Resonance (SPR). Metode yang dilakukan dalam pembuatan aplikasi dimulai dari tahap analisis, tahap desain interface, tahap coding dan tahap pengujian. Tombol Kurva simulasi pada menu editor berisi perintah untuk menampilkan spektrum SPR simulasi berdasarkan data indeks bias dan ketebalan yang dimasukkan dalam data input. Sedangkan Kurva Eksperimen berisi perintah untuk menampilkan titik - titik hasil eksperimen. Akhirnya sensitifitas dari biosensor berbasis SPR dapat ditentukan nilainya dengan mengganti nilai - nilai pada penel input data. Selain itu sistem SPR yang tidak diketahui nilai indeks bias dan ketebalannya dapat diprediksi nilainya dengan membandingkan kurva simulasi dan kurva eksperimen.
\end{abstract}

Kata Kunci: Surface Plasmon Resonance; GUI MATLAB

\section{Graphical User Interface (GUI) MATLAB Implementation to Analyze the Spectrum of Surface Plasmon Resonance (SPR) Biosensor}

\begin{abstract}
This study aims to create a simple application based using GUI MATLAB to analyze the spectrum of Surface Plasmon Resonance (SPR) biosensor. Methods in making applications starting from the analysis stage, interface design stage, coding stage and testing stage. Botton "Kurva Simulasi" in editor menu contains commands to display the simulation of SPR spectrum based on refractive index and thickness entered in the input data. Botton "Kurva Eksperimen" contains a command to display the experiment result points. Finally the sensitivity of the SPR system can be determined by replacing the values in the data input. In addition the unrecognized $S P R$ system of refractive index values and their thickness can be predicted by comparing the simulation curve and the experimental curve.
\end{abstract}

Keywords: Surface Plasmon Resonance; GUI MATLAB.

\section{PENDAHULUAN}

Biosensor merupakan suatu perangkat yang digunakan untuk mempelajari interaksi biomolekular. Perangkat ini telah banyak diaplikasikan dalam berbagai produk teknologi seperti food safety, diagnosa medis dan monitoring lingkungan. Salah satu biosensor yang banyak digunakan dan dikaji saat ini adalah biosensor berbasis surface plasmon resonance (SPR) (Sipova, 2013, p.9). SPR merupakan salah satu jenis biosensor optik yang mana sangat sensitif terhadap perubahan indeks bias pada permukaan sensing (Nguyen, 2015, p.10482). Indeks bias dari sebuah material dapat dinyatakan dengan (Fox, 2010, p.7) : 


\section{Jurnal Pendidikan Fisika dan Keilmuan (JPFK), 4 (4), 2018 - 56}

Devi Taufiq Nurrohman, Riyadi Purwanto

$$
\tilde{n}=n+i \kappa
$$

Dimana $\tilde{n}$ menyatakan indeks bias kompleks dari material, $n$ menyatakan komponen real dari indeks bias dan $\kappa$ menyatakan komponen imajiner dari indeks bias. Indeks bias material berhubungan dengan konstanta dielektrik $\widetilde{\varepsilon}_{r}$ yang dinyatakan dengan :

$$
\tilde{\varepsilon}_{r}=\varepsilon_{1}-i \varepsilon_{2}
$$

Dimana $\varepsilon_{1}=n^{2}-\kappa^{2}$ dan $\varepsilon_{2}=2 n \kappa$ secara berturut-turut merupakan bagian real dan kompleks dari nilai konstanta dielektrik.

Ketika sebuah prisma dengan indeks bias $n_{p}$ ditembak dengan laser yang terpolarisasi tipe $\mathrm{p}$ dengan sudut datang $\theta$,

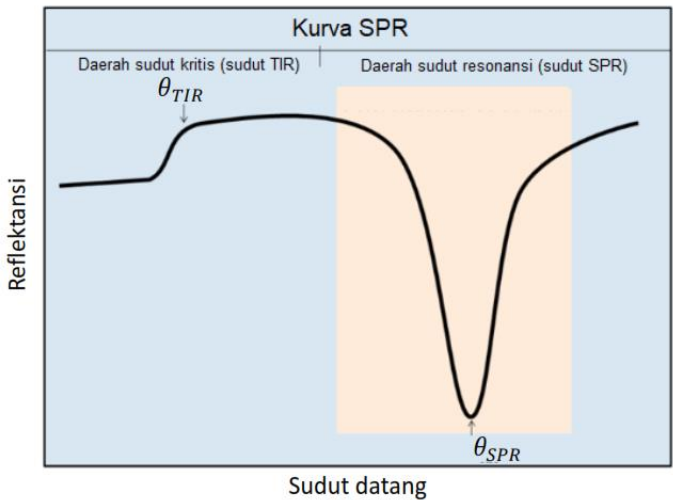

Gambar 1. Sudut TIR dan sudut SPR pada kurva SPR (Jang, 2015, p.25387).

Kondisi resonansi pada kurva SPR memenuhi persamaan dibawah ini (Maharana, 2013, p.1)

$$
\frac{2 \pi}{\lambda_{0}} n_{p} \sin \theta_{S P R}=\operatorname{Re}\left[\frac{2 \pi}{\lambda}\left(\frac{\varepsilon_{m} \varepsilon_{d}}{\varepsilon_{m}+\varepsilon_{d}}\right)\right]
$$

maka pada sudut tertentu cahaya akan sepenuhnya dipantulkan oleh prisma. Sudut pada saat cahaya sepenuhnya dipantulkan disebut dengan sudut TIR (total internal reflection). Kemudian ketika permukaan prisma dideposisikan dengan lapisan tipis logam dan cahaya terpolarisasi tipe $p$ diarahkan pada permukaan prisma maka akan mengeksitasi gelombang surface plasmon (SP) disepanjang permukaan logam dan dielektrik (udara) yang mana pada saat sudut tertentu akan mengalami kondisi resonansi disebut dengan sudut SPR. Gambar 1 menggambarkan letak sudut TIR dan sudut SPR pada kurva SPR.

Dimana $\theta_{S P R}$ adalah sudut resonansi, $n_{p}$ adalah indeks bias prisma, $\varepsilon_{d}$ adalah konstanta dielektrik dari lapisan sensing (analyte), $\lambda$ adalah panjang gelombang laser yang digunakan dan $\varepsilon_{m}$ adalah konstanta dielektrik dari lapisan tipis logam. Skema eksperimen pada biosensor berbasis SPR dan kurva reflektansi SPR ditunjukkan pada gambar 2.

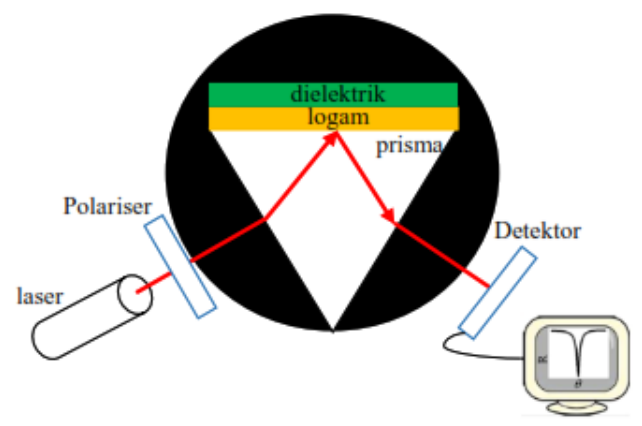

Gambar 2. Skema Eksperimen Biosensor Berbasis SPR dan Kurva Reflektansinya

Penelitian ini bertujuan untuk mengimplementasikan salah satu fitur dalam MATLAB yaitu Graphical User Interface (GUI) sebagai aplikasi dekstop dalam menganalisis spektrum SPR. Sebetulnya simulasi SPR dapat dilakukan dengan menggunakan software WINSPALL, namun untuk tujuan tertentu terkadang membutuhkan informasi yang tidak ditemukan pada software tersebut. Oleh karena itu pada penelitian ini 
mencoba untuk membuat aplikasi dekstop sederhana sehingga bisa disesuaikan dengan data yang kita butuhkan untuk analisis kurva SPR. Simulasi biosensor berbasis SPR sebetulnya pernah dilakukan diantaranya simulasi pengaruh ketebalan lapisan nanopartikel $\mathrm{Fe}_{3} \mathrm{O}_{4}$ terhadap respon biosensor SPR dan kajian pengaruh material graphene pada kinerja biosensor berbasis SPR (Yanti, 2017, p.1) (Sari, 2012, p.77). Simulasi yang dilakukan kedua peneliti tersebut belum sampai ke pembuatan interface dalam bentuk aplikasi dekstop. Ini merupakan salah satu yang mendorong topik penelitian ini. Aplikasi ini diharapkan nantinya dapat dimanfaatkan untuk menganalisis spektrum SPR baik untuk mengetahui sensitifitasnya maupun untuk memperkirakan indeks bias dan ketebalan material pada sistem SPR yang diperoleh dari data eksperimen.

\section{METODE}

Dalam membuat aplikasi dekstop untuk menganalisis spektrum SPR ini, penelitian ini terbagi menjadi 4 tahapan yaitu tahap analisis, tahap desain interface, tahap coding dan tahap pengujian/testing.

Tahap analisis dilakukan dengan menentukan formula yang akan dibutuhkan dalam aplikasi. Spektrum SPR diperoleh dari hasil plotting sudut datang pada sumbu $x$ dan reflektansi pada sumbu y. Reflektansi dari sebuah sistem SPR yang terdiri dari 3 lapisan yaitu prisma $(p)$, logam $(m)$ dan $\operatorname{dielektrik}(d)$ dapat dinyatakan dengan (Michel, 2017, p.259)

$$
\begin{aligned}
R & =\left|r_{p m d}\right|^{2} \\
& =\left|\frac{r_{p m}+r_{m d} e^{2 i k_{m z} d_{m}}}{1+r_{p m} r_{m d} e^{2 i k_{m z} d_{m}}}\right|^{2}
\end{aligned}
$$

Dimana :

$$
\begin{gathered}
r_{p m}=\frac{k_{p z} \varepsilon_{m}-k_{m z} \varepsilon_{p}}{k_{p z} \varepsilon_{m}+k_{m z} \varepsilon_{p}} \\
r_{m d}=\frac{k_{m z} \varepsilon_{d}-k_{s z} \varepsilon_{m}}{k_{m z} \varepsilon_{d}+k_{s z} \varepsilon_{m}} \\
k_{j z}=\frac{\omega}{c} \sqrt{\varepsilon_{j}-\varepsilon_{p} \sin ^{2} \theta}
\end{gathered}
$$

Dimana $d_{m}$ pada persamaan 4 menunjukkan ketebalan dari lapisan tipis logam, $j$ pada persamaan 6 dapat berupa $p, m, d$ menunjukkan perambatan konstanta gelombang yang tegak lurus dengan permukaan bidang dan $\omega=2 \pi c /$ $\lambda$ serta $c$ menunjukkan kecepatan dari cahaya.

Tahap desain interface dimulai dengan pembuatan diagram alir dari persamaan yang digunakan dalam tahap analisis. Setelah itu dilanjutkan dengan pembuatan interface dari diagram alir yang telah dibuat menggunakan GUI MATLAB. Diagram alir pada penelitian ini ditunjukkan pada Gambar 3.

Tahap coding adalah tahap penulisan coding pada setiap toolbar yang digunakan pada tahap desain interface. Penulisan coding bertujuan agar seluruh toolbar yang digunakan pada tahap desain interface dapat berinteraksi satu sama lain dan bekerja sesuai dengan yang direncanakan. Hasil akhir dari tahap ini adalah sebuah aplikasi dekstop untuk melakukan analisis spektrum SPR.

Tahap pengujian/testing pada penelitian ini dilakukan dengan melakukan input variabel pada panel input data dan kemudian melihat hasilnya pada panel output. Output tersebut nantinya akan dibandingkan dengan hasil penelitian lain yang telah dipublikasikan untuk memastikan bahwa hasil didapatkan telah sesuai. 
Jurnal Pendidikan Fisika dan Keilmuan (JPFK), 4 (4), 2018 - 58

Devi Taufiq Nurrohman, Riyadi Purwanto

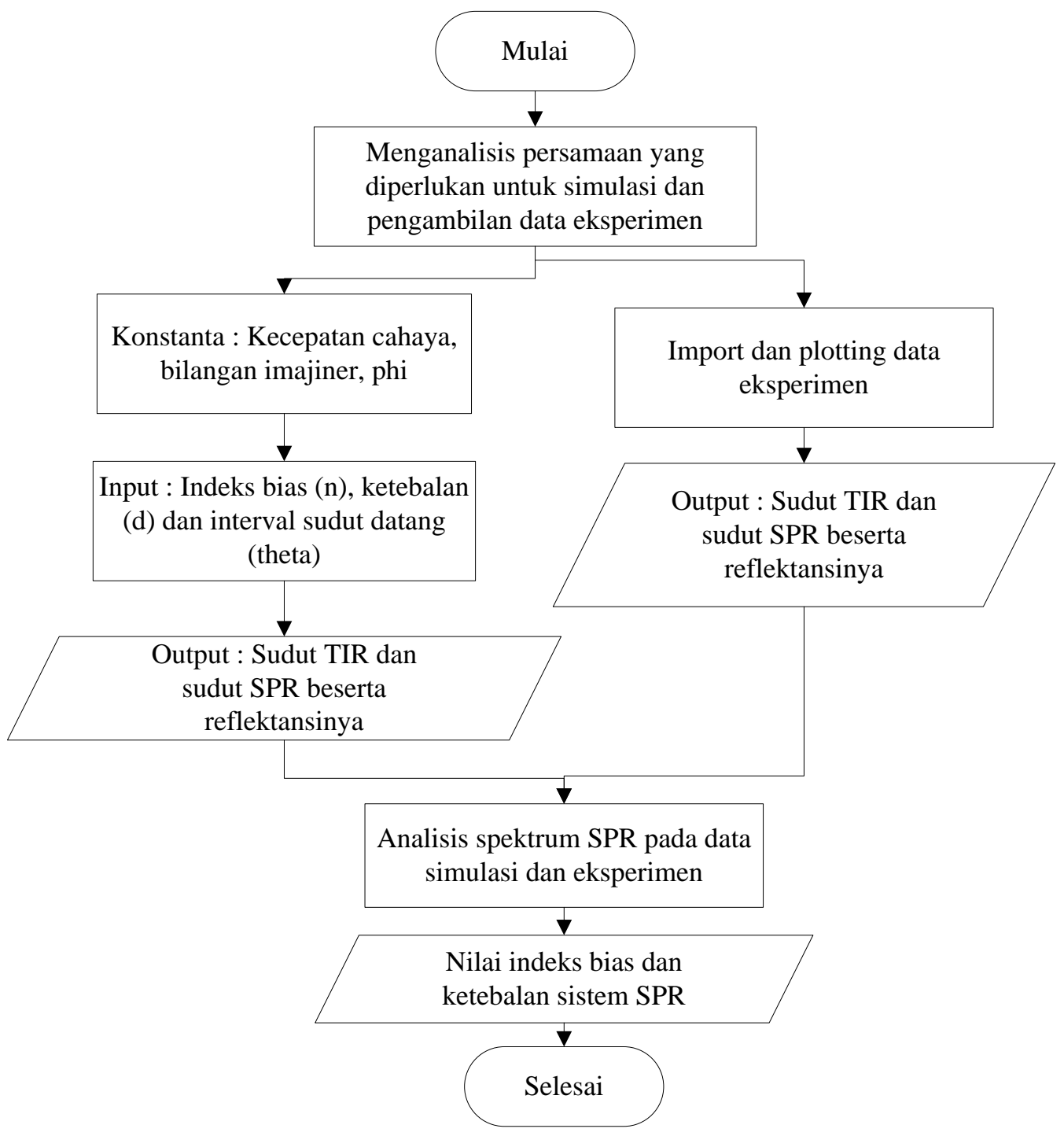

Gambar 3. Flowchart aplikasi secara umum

\section{HASIL DAN PEMBAHASAN}

Berdasarkan diagram alir yang ditunjukkan pada Gambar 3, desain interface ditunjukkan pada Gambar 4. Terdapat 4 panel dan satu grafik. Panel yang pertama berisi input data yang dimasukkan untuk melihat spektrum hasil simulasi. Data yang diinputkan meliputi nilai panjang gelombang yang digunakan, indeks bias dari prisma, logam dan dielektrik serta ketebalan dari logam. Panel yang kedua berfungsi untuk mengatur sudut datang pada kurva simulasi. Sedangkan panel yang ketiga dan keempat berturut - turut berfungsi untuk menampilkan output data meliputi nilai sudut kritis (TIR) dan sudut SPR beserta nilai reflektansinya untuk spektrum SPR hasil simulasi dan eksperimen. Sedangkan menu pada sebelah kiri atas berupa menu "Kurva Simulasi" dan "Kurva Eksperimen" berfungsi sebagai tombol untuk menampilkan kurva SPR hasil simulasi dan eksperimen. 
Jurnal Pendidikan Fisika dan Keilmuan (JPFK), 4 (4), 2018 - 59

Devi Taufiq Nurrohman, Riyadi Purwanto

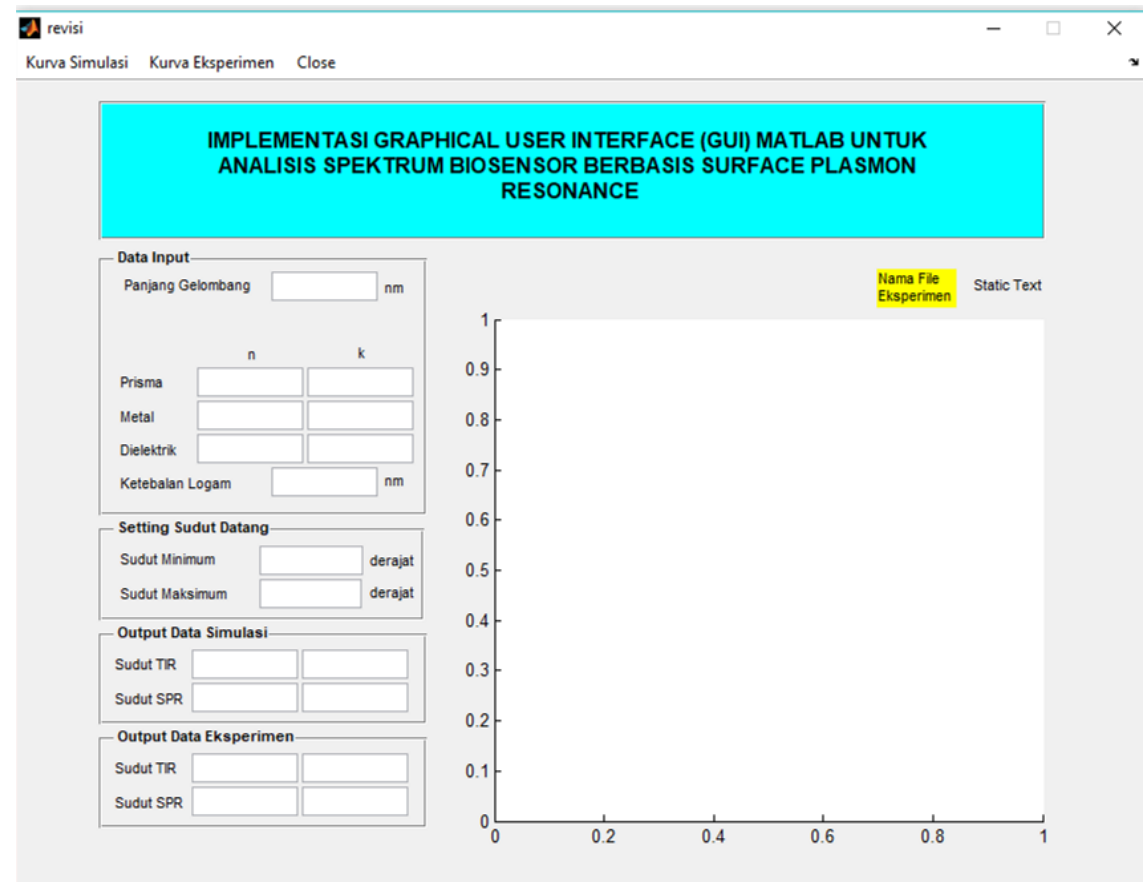

Gambar 4. Tampilan desain interface aplikasi

Tombol "Kurva Simulasi" dan "Kurva Eksperimen" dalam penelitian ini dibuat dalam bentuk menu editor. Kurva simulasi berfungsi untuk melakukan proses perhitungan nilai reflektansi sebagai variasi dari sudut datang $(\theta)$. Nilai sudut datang dan reflektansinya akan secara otomatis ditampilkan pada grafik sedangkan nilai sudut TIR dan SPR beserta nilai reflektansinya akan ditampilkan pada panel Output Data Simulasi. Berikut adalah potongan listing program untuk Kurva Simulasi.

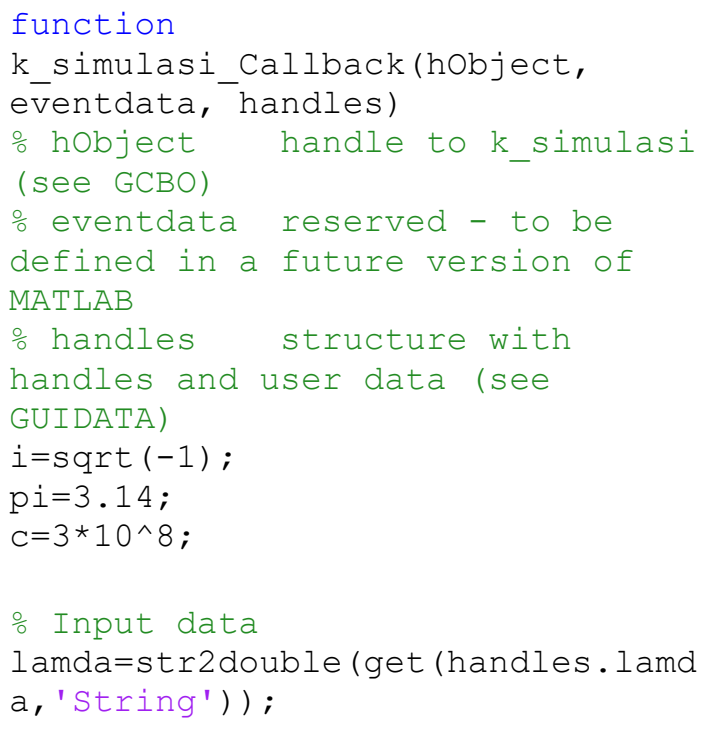

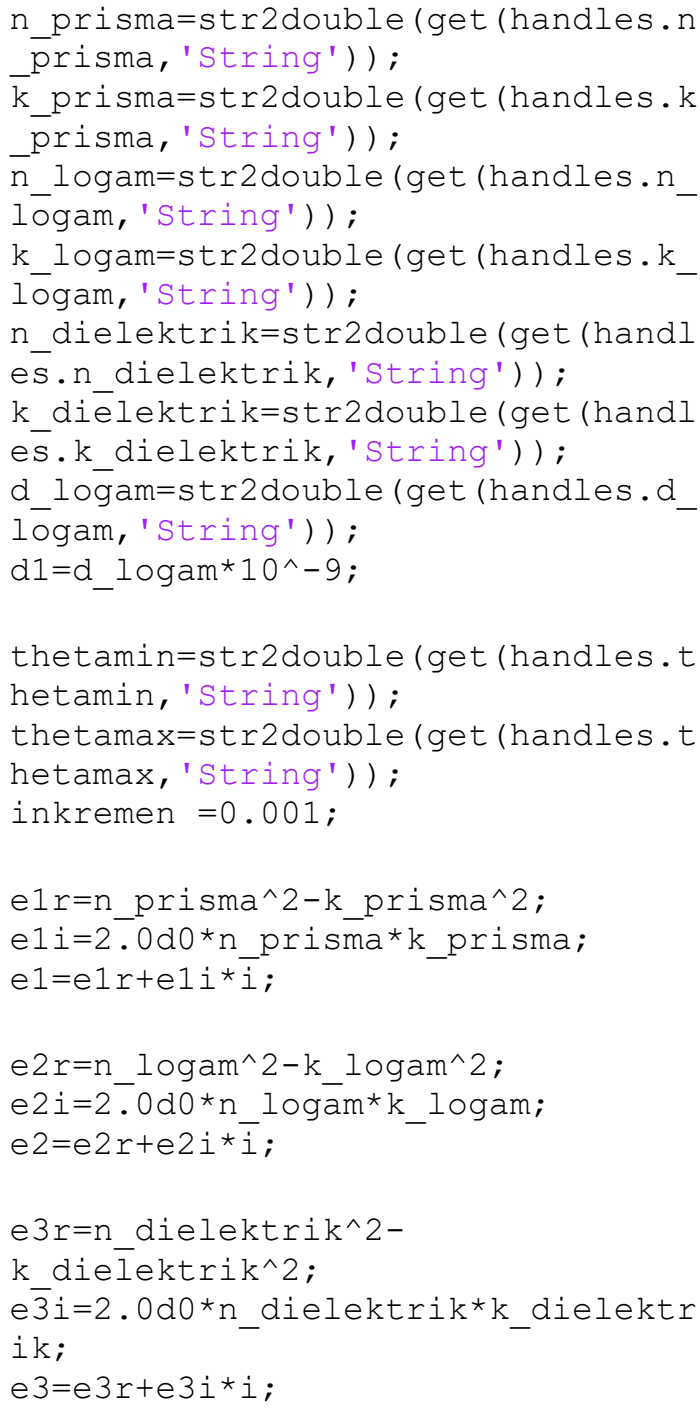




\section{Jurnal Pendidikan Fisika dan Keilmuan (JPFK), 4 (4), 2018 - 60}

Devi Taufiq Nurrohman, Riyadi Purwanto

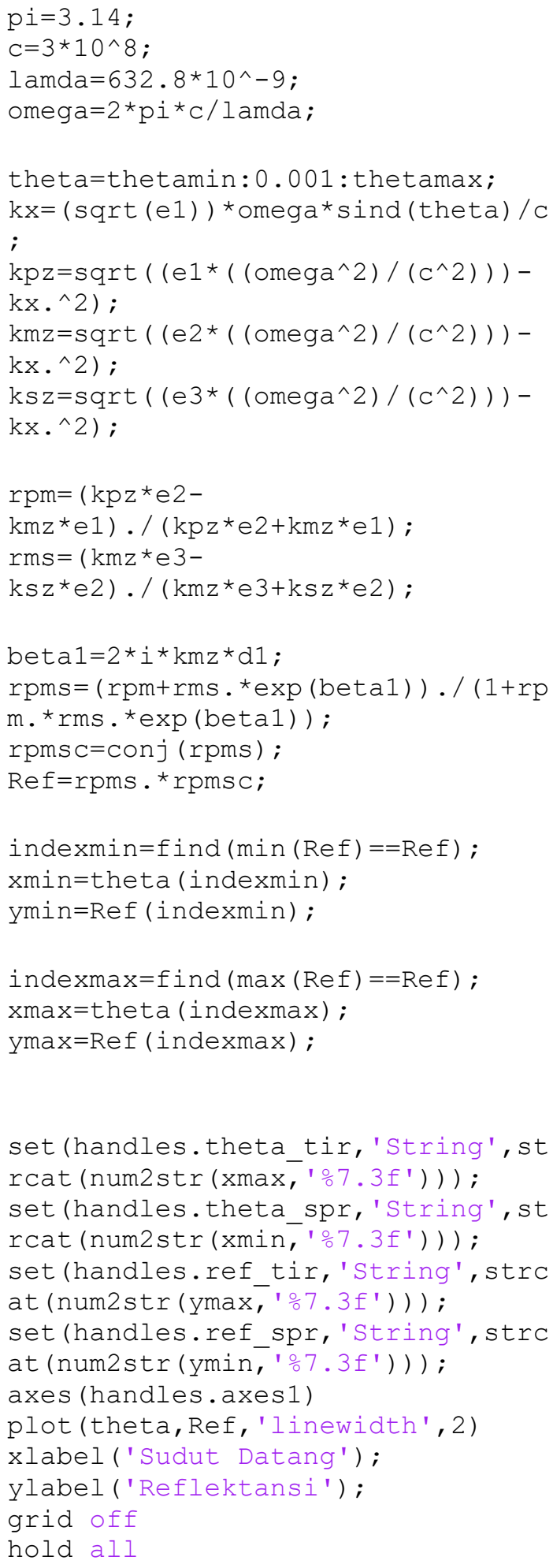

\section{Tombol "Kurva Eksperimen"} berfungsi sebagai tombol yang berisi perintah untuk melakukan import data eksperimen dan menampilkan data eksperimen tersebut dalam grafik yang sama dengan kurva simulasi. Berikut adalah potongan listing program untuk Kurva Eksperimen.

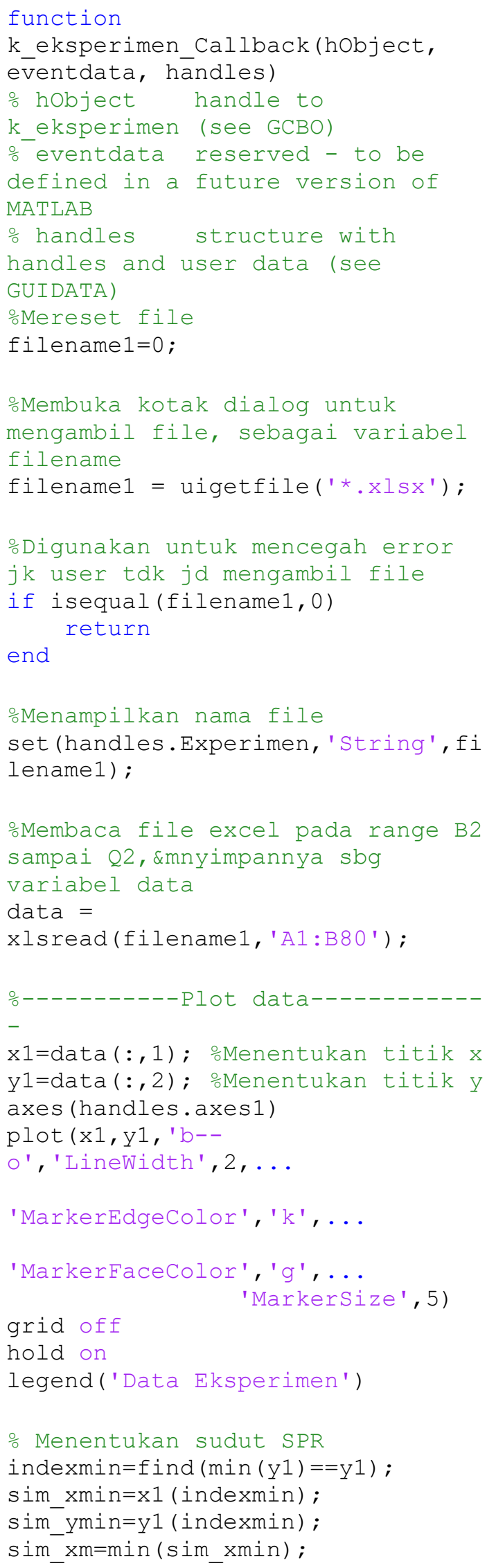


sim_ym=min (sim_ymin)

o Menentukan sudut kritis

indexmax $=$ find $(\max (\mathrm{y} 1)==\mathrm{y} 1)$;

sim_xmax $=x 1$ (indexmax);

sim_ymax $=y 1$ (indexmax);

set (handles.theta_spre, 'string', s trcat (num2str ( $\left.\left.\operatorname{sim}^{-} \mathrm{xm}, \mathrm{\prime}^{\circ} 7.2 \mathrm{f}^{\prime}\right)\right)$ )); set (handles.ref spre, 'string', str cat (num2str(sim_ym, '⒎3f'))) ; set (handles.theta tire, 'string', s trcat (num2str(sim_xmax,' $\left.\frac{0}{0} 7.2 f^{\prime}\right)$ )) ;

set (handles.ref_tire, 'string', str cat (num2str(sim_ymax,' '⒎3f'))) ;
Kurva Eksperimen ditunjukkan pada Gambar 5. Kurva simulasi ditunjukkan dengan spektrum SPR garis berwarna merah sedangkan kurva eksperimen ditunjukkan dengan spektrum SPR garis berwarna biru dengan kotak kecil berwarna hijau yang mana menunjukkan titik - titik pengukuran hasil eksperimen. Hasil pengujian menunjukkan bahwa aplikasi mampu bekerja sesuai fungsionalitasnya yaitu untuk menampilkan kurva simulasi dan kurva eksperimen.

Hasil pengujian terhadap fungsionalitas tombol Kurva Simulasi dan

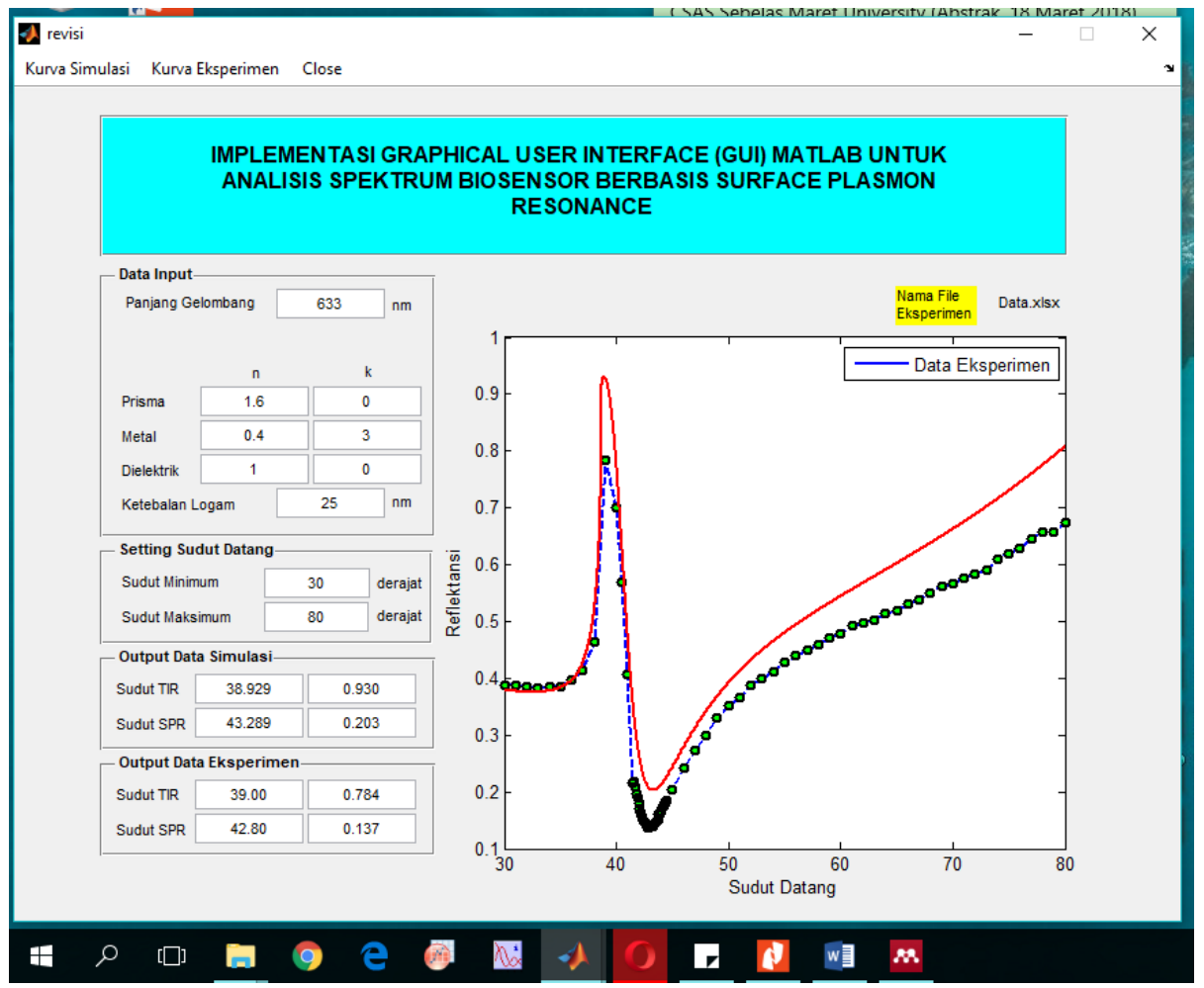

Gambar 5. Pengujian fungsionalitas tombol "Kurva Simulasi" dan Kurva Eksperimen

Setelah melakukan pengujian terhadap fungsionalitas kurva simulasi dan kurva eksperimen, dilakukan validasi spektrum SPR yang dihasilkan oleh kurva simulasi. Gambar 6b menunjukkan kurva SPR berdasarkan penelitian yang dilakukan oleh Meng dkk pada tahun 2017. Dengan memasukkan nilai panjang gelombang $(\lambda)=632,8 \mathrm{~nm}$, indeks bias prisma $\left(n_{p}\right)=1,732$, indeks bias logam $n_{m}=0,13+3,99 i$, ketebalan logam $d_{m}=47 \mathrm{~nm}$ dan indeks bias dielektrik (air) $n_{2}=1,33$ maka diperoleh spektrum SPR yang ditunjukkan pada gambar 6 . 


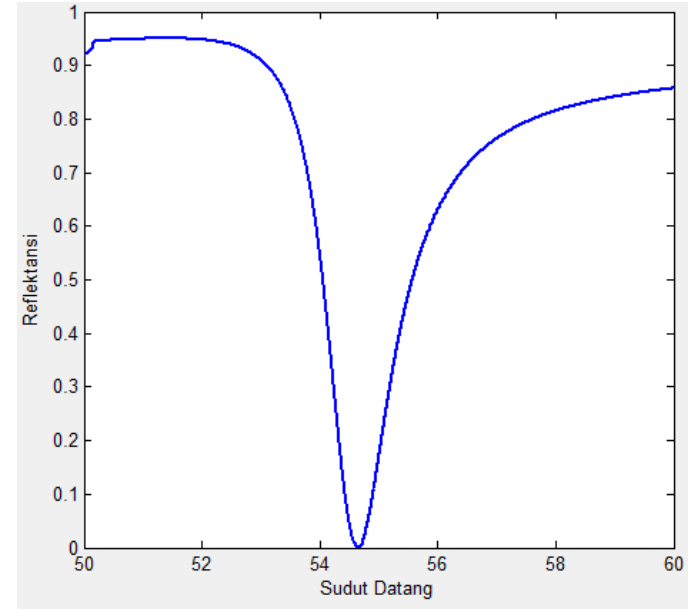

(a)

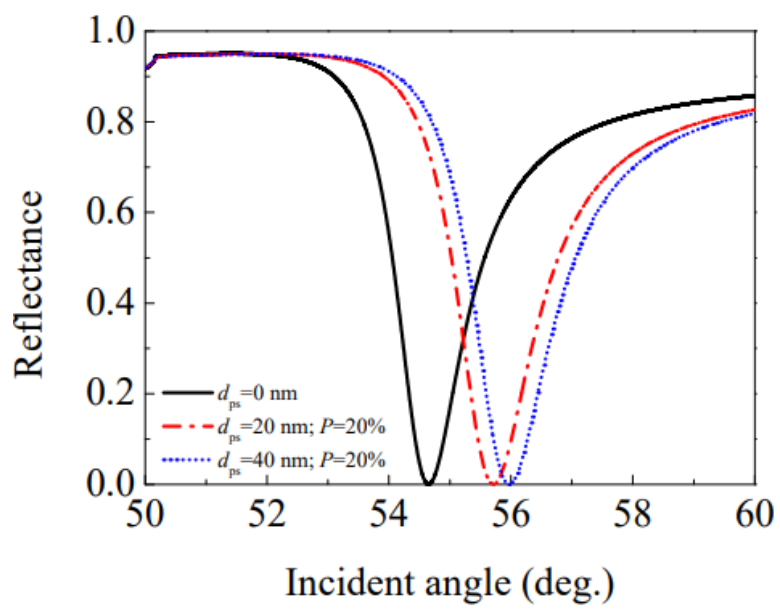

(b)

Gambar 6. Validasi spektrum SPR (a). Spektrum SPR yang dihasilkan menggunakan GUI MATLAB (b). Spektrum SPR yang sudah dipublikasikan (garis berwarna hitam) (Meng , 2017, p.5)

Dari data output kurva simulasi diperoleh bahwa nilai sudut TIR adalah $51,43^{\circ}$ dengan nilai reflektansi 0,95 sedangkan sudut SPR adalah $54,65^{\circ}$ dengan nilai reflektansi 0. Berdasarkan nilai sudut TIR dan sudut SPR, maka dapat disimpulkan bahwa simulasi menggunakan GUI MATLAB ini telah dapat diimplementasikan dan dapat digunakan untuk analisis spektrum SPR.

Analisis spektrum SPR yang dapat dilakukan menggunakan aplikasi dekstop ini antara lain simulasi untuk melihat sensitifitas biosensor berbasis SPR pada sistem SPR 3 lapisan (prisma, logam dan dielektrik). Sensitifitas biosensor berbasis SPR didefinisikan sebagai perbandingan perubahan sudut SPR $\left(\Delta \theta_{S P R}\right)$ terhadap perubahan indeks bias pada permukaan dielektrik $\left(\Delta n_{d}\right)$ seperti yang ditunjukkan pada persamaan berikut (Ouyang, 2016, p.136):

$$
S=\frac{\Delta \theta_{S P R}}{\Delta n_{d}}
$$

Dimana $S$ menunjukkan sensitifitas dari biosensor berbasis SPR. Sebagai contoh berikut menunjukkan sensitifitas dari biosensor berbasis SPR pada dua logam berbeda emas $(\mathrm{Au})$ dan perak (Ag). Gambar 7 menunjukkan kurva simulasi SPR untuk emas dan perak dengan tebal $50 \mathrm{~nm}$ dengan indeks bias dielektrik 1 , 1,04 dan 1,06. Prisma yang digunakan dalam simulasi ini pada panjang gelombang $633 \mathrm{~nm}$ memiliki indeksi bias $\left(n_{p}=1,732\right)$. Indeks bias emas adalah $n_{A u}=0,1726+i 3,4218$ (Ouyang, 2016, p.4). Sedangkan indeks bias perak adalah $n_{A g}=0,056+i 4,276 \quad$ (Fouad, 2016, p.6). Secara lengkap data yang diperoleh dari simulasi ditunjukkan pada Tabel 1. 


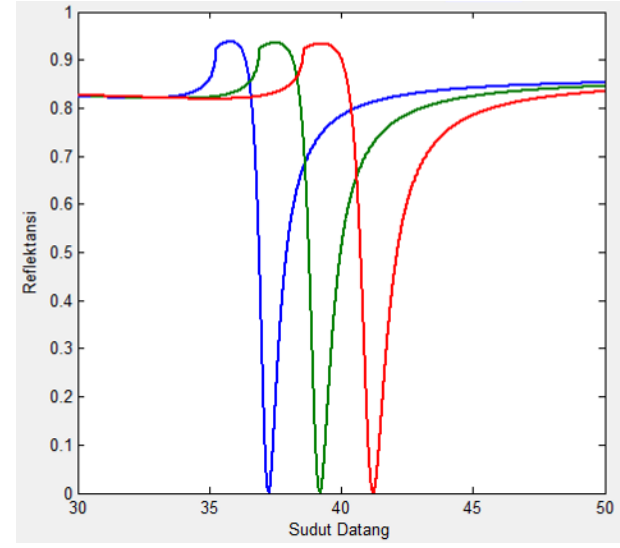

(a)

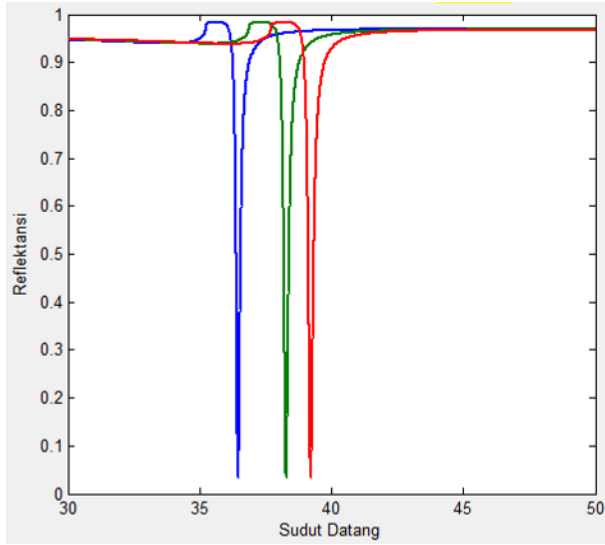

(b)

Gambar 7. Kurva simulasi SPR untuk lapisan tipis logam $50 \mathrm{~nm}$ dengan indeks bias dielektrik $n_{d}$ adalah 1 (biru), 1,04 (hijau) dan 1,08 (merah) untuk (a). Emas, (b). Perak.

Berdasarkan Tabel 1 dapat dilihat bahwa untuk indeks bias yang sama, nilai perubahan sudut SPR pada lapisan tipis emas selalu lebih besar daripada lapisan tipis perak. Hal tersebut menunjukkan

Tabel 1. Perubahan sudut SPR pada beberapa nilai indeks bias dielektrik

\begin{tabular}{ccccccc}
\hline $\begin{array}{c}\text { Jenis } \\
\text { logam }\end{array}$ & $\begin{array}{c}\text { Indeks Bias } \\
\text { Dielektrik } \\
\left(n_{d}\right)\end{array}$ & $\begin{array}{c}\text { Sudut TIR } \\
\theta_{T I R}\end{array}$ & Reflektansi & $\begin{array}{c}\text { Sudut SPR } \\
\theta_{S P R}\end{array}$ & Reflektansi & $\Delta \theta_{S P R}$ \\
\hline Emas & 1,00 & 35,822 & 0,938 & 37,255 & 0,001 & 0 \\
& 1,02 & 36,673 & 0,937 & 38,218 & 0,001 & 0,963 \\
& 1,04 & 37,534 & 0,936 & 39,199 & 0,001 & 1,944 \\
& 1,06 & 38,406 & 0,935 & 40,199 & 0,001 & 2,944 \\
& 1,08 & 39,289 & 0,934 & 41,220 & 0,001 & 3,965 \\
& 1,10 & 40,184 & 0,932 & 42,263 & 0,001 & 5,008 \\
\hline Perak & 1,00 & 35,729 & 0,984 & 36,467 & 0,032 & 0 \\
& 1,02 & 36,575 & 0,983 & 37,371 & 0,032 & 0,904 \\
& 1,04 & 37,432 & 0,983 & 38,289 & 0,033 & 1,822 \\
& 1,06 & 38,300 & 0,983 & 39,222 & 0,033 & 2,755 \\
& 1,08 & 39,179 & 0,983 & 40,171 & 0,033 & 3,704 \\
& 1,10 & 40,070 & 0,982 & 41,137 & 0,034 & 4,670 \\
\hline
\end{tabular}

Berdasarkan pada data Tabel 1., kita dapat menentukan sensitivitas dari biosensor berbasis SPR dengan melakukan ploting dengan sumbu $\mathrm{x}$ adalah perubahan indeks bias pada dielektrik $\left(\Delta n_{d}\right)$ dan sumbu y adalah perubahan sudut SPR-nya $\left(\Delta \theta_{S P R}\right)$. Dengan menentukan gradien pada lapisan tipis emas dan perak maka sensitifitas dari biosensor berbasis SPR untuk masing - bahwa berdasarkan perubahan sudut SPR, lapisan tipis emas menunjukkan sensitifitas yang lebih baik daripada lapisan tipis perak. 


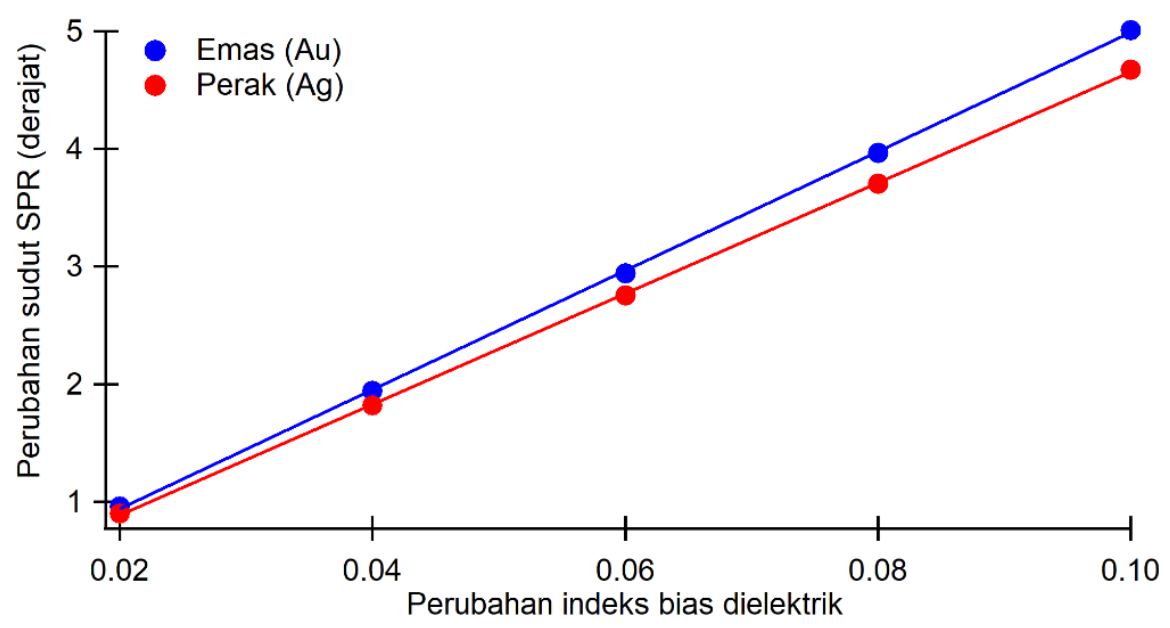

Gambar 8. Grafik perubahan indeks bias dielektrik dan perubahan sudut SPR

Selain dapat digunakan untuk ketebalan dari logam kemudian dapat menentukan sensitifitas dari biosensor diprediksi dengan cara mengganti nilai berbasis SPR, aplikasi dekstop ini juga pada panel data input. Gambar 9 dapat digunakan sebagai pendekatan menunjukkan titik-titik pengukuran pada untuk menentukan nalai indeks bias dan ketebalan logam dari sistem SPR yang terdiri dari prisma, logam dan dielektrik. Data eksperimen terlebih dahulu ditampilkan dalam aplikasi dengan menekan tombol "Kurva Eksperimen" pada menu bar. Nilai dari indeks bias dan saat eksperimen yang ditunjukkan dengan titik berwarna hijau yang dihubungkan dengan garis biru sedangkan garis merah menunjukkan kurva simulasi. Indeks bias dan ketebalan logam pada Gambar 9 ditunjukkan pada Tabel 2.

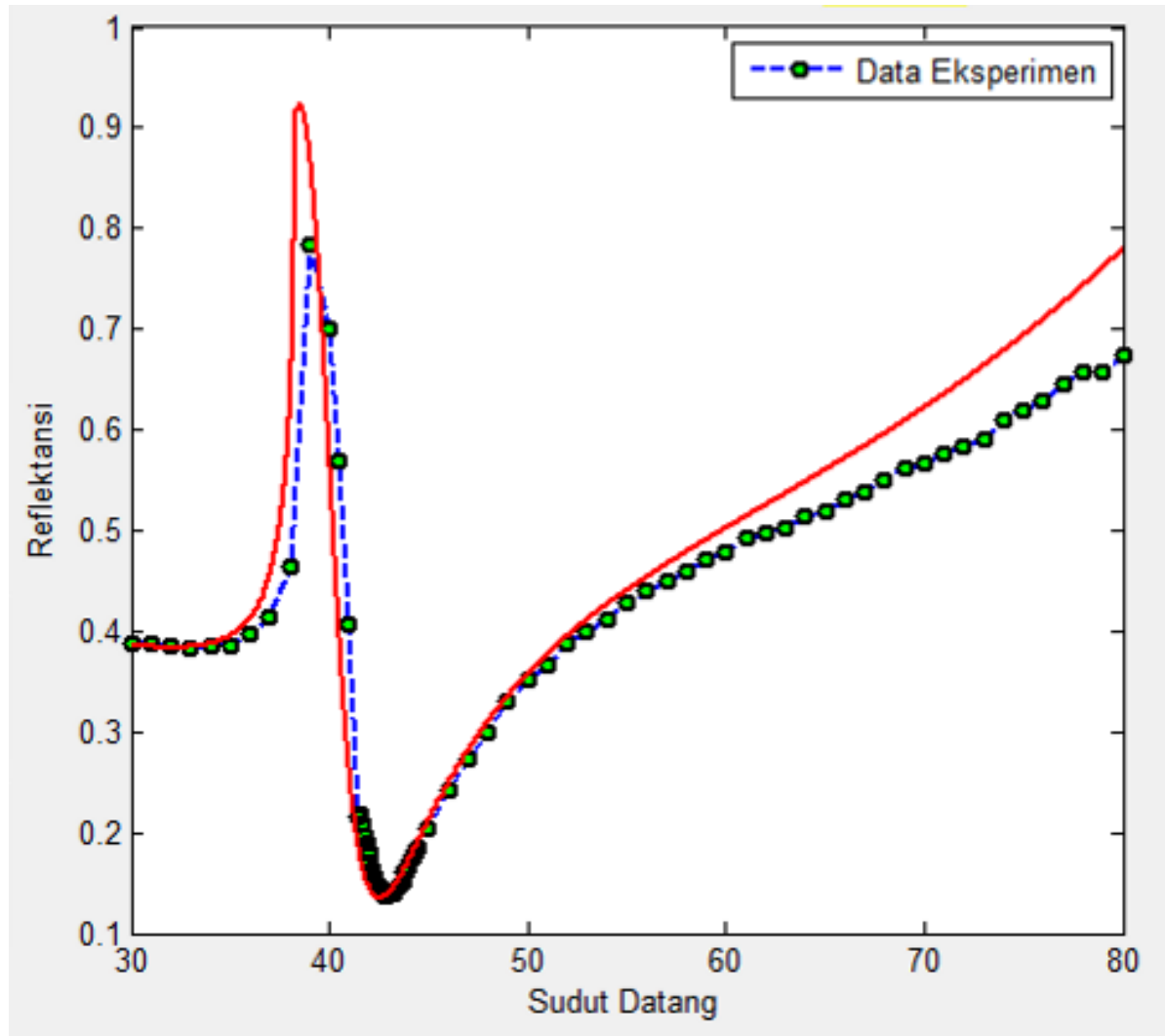

Gambar 9. Pendekatan nilai indeks bias dan ketebalan dari sistem SPR berdasarkan data eksperimen 
Kurva simulasi pada spektrum SPR merupakan kurva ideal yang seharusnya terbentuk pada spektrum SPR. Pada saat pengambilan data eksperimen, kurva ini akan sulit terbentuk dikarenakan pada saat eksperimen dipengaruhi oleh beberapa variabel saat pengukuran seperti stabilitas laser dan kondisi ruangan saat pengukuran. Belum lagi error yang bersumber dari perangkat seperti kemampuan detektor untuk mengukur cahaya yang dipantulkan maupun resolusi dari motor yang mempengaruhi banyaknya data yang diperoleh.

Tabel 2. Indeks bias prisma, logam dan dielektrik dan ketebalan logamnya

\begin{tabular}{ccccc}
\hline Material & Ketebalan $(\mathbf{n m})$ & $\boldsymbol{n}$ & Indeks Bias & $\boldsymbol{\kappa}$ \\
\hline Prisma & 0 & 1,615 & 0 \\
Logam & 25 & 0,47 & 3,1 \\
Dielektrik (udara) & 0 & 1 & 0 \\
\hline
\end{tabular}

\section{SIMPULAN}

Berdasarkan pembahasan diatas, dapat disimpulkan bahwa aplikasi dekstop untuk analisis kurva SPR telah berhasil diimplementasikan. Analisis kurva SPR yang diimplementasikan dibatasi hanya untuk sistem SPR tiga lapisan yaitu prisma, logam dan dielektrik. Sensitifitas dari sistem SPR

\section{DAFTAR PUSTAKA}

Fouad, S., Sabri, N., \& Poopalan, P. (2016). Enhanced Sensitivity of Surface Plasmon Resonance Sensor Based on Bilayers of Silver-Barium Titanate. Journal of Nano- and Electronic Physics, 8(4), 2-6.

Fox, M. (2010). Optical Properties of Solids (Second Edi). New York: Oxford University Press.

Jang, D., Chae, G., \& Shin, S. (2015). Analysis of Surface Plasmon Resonance Curves with a Novel SigmoidAsymmetric Fitting Algorithm. Sensors, 15, 25385-25398.

Maharana, P. K., Bharadwaj, S., Jha, R., Maharana, P. K., Bharadwaj, S., \& Jha, R. (2013). Electric field enhancement in surface plasmon resonance bimetallic configuration based on chalcogenide prism Electric field enhancement in surface plasmon resonance bimetallic configuration based on chalcogenide prism. Journal of Applied Physics, 014304(1), 1-4. untuk material berbeda dapat ditentukan dengan memasukkan nilai indeks bias dan ketebalan pada panel Data Input. Selain itu, sistem SPR yang tidak diketahui nilai indeks bias dan ketebalannya dapat diprediksi nilainya dengan membandingkan kurva simulasi dan kurva eksperimen.

Meng, Q., Zhao, X., Lin, C., Chen, S., Ding, Y., \& Chen, Z. (2017). Figure of Merit Enhancement of a Surface Plasmon Resonance Sensor Using a LowRefractive-Index Porous Silica Film. Sensors, 17(1846), 1-11.

Michel, D., Xiao, F., \& Alameh, K. (2017). A compact, flexible fiber-optic Surface Plasmon Resonance sensor with changeable sensor chips with changeable sensor chips. Sensors and Actuators B: Chemical (Vol. 246).

Nguyen, H. H., Park, J., Kang, S., \& Kim, M. (2015). Surface Plasmon Resonance: A Versatile Technique for Biosensor Applications. Sensors, 15, 1048110510.

Ouyang, Q., Zeng, S., Dinh, X., \& Coquet, P. (2016). Sensitivity Enhancement of MoS 2 Nanosheet based Surface Plasmon Resonance Biosensor. Procedia Engineering, 140, 134-139.

Sari, R., \& Abraha, K. (2012). Simulasi Pengaruh Ketebalan Lapisan 
Jurnal Pendidikan Fisika dan Keilmuan (JPFK), 4 (4), 2018 - 66

Devi Taufiq Nurrohman, Riyadi Purwanto

Nanopartikel Magnetik ( Fe 3 O 4 ) terhadap Respon Biosensor Berbasis Surface Plasmon Resonance ( SPR ) untuk Deteksi DNA. In Prosiding Pertemuan Ilmiah XXVI HFI Jateng \& $D I Y$ (pp. 77-81).

Sipova, H., Zhang, S., Dudley, A., Galas, D., Wang, K., \& Homola, J. (2010). Surface Plasmon Resonance Biosensor for Rapid Label-Free Detection of Microribonucleic Acid at Subfemtomole
Level ^1. Anal. Chem, 82(24), 1011010115.

Yanti, W., \& Melati, A. (2017). Kajian Pengaruh Material Graphene pada kinerja Biosensor Berbasis Surface Plasmon Resonance ( SPR ) pada Deteksi Makanan Halal sebagai Pendukung Halal Research Center UIN Sunan Kalijaga Yogyakarta. Indonesian Journal of Applied Physics, 7(1), 1-9. 